\title{
Applying Internet Resources to Aiding Chinese Learners of Chinese-English Translation
}

\author{
Xiaonong Wang \\ College of Foreign Languages, Nankai University, Tianjin, China; \\ School of Foreign Languages, Ludong University, Yantai, China \\ Bo Chang \\ Multimedia Teaching Management Department, Ludong University, Yantai, China
}

\begin{abstract}
Efficient translation teaching is important to nourishment of translation talents. It is imperative to explore ways of applying Internet resources to translation teaching in order to enhance the performance of teaching the C-E translation course to Chinese EFL majors, and translation experiments can be considered as a way which will probably bring about remarkable teaching results. Through designing and making translation experiment, the teacher-learner interactive relationship will be strengthened, and the learners' learning initiative on an autonomous basis can be more aroused in developing their C-E translation ability, thus enhancing translation teaching efficiency. The design of the $\mathrm{C}$-E translation experiments should be governed by some principles and oriented to developing the translation competence of the learners by imitating real conditions where professional translators work.
\end{abstract}

Index Terms-Chinese-English translation teaching, Internet resources, experiment, Chinese EFL majors

\section{INTRODUCTION}

Coupled with the flourishing international communication between China and other countries is the bigger and bigger role assumed by translation between Chinese and English; hence the increasing demand of translation practitioners. Since in a long period in future the foreign languages departments of Chinese universities will remain the major source where translators come forth (Bao, 2003), the performance of teaching translation between English and Chinese in Chinese universities is of significance. Unfortunately, the translating abilities of the graduating EFL majors of universities in China have on the whole suffered a noticeable decline in recent years, thus calling for efforts of researching for more effective translation teaching models and methods. As the computer and the online resources are now indispensable to the professional pursuits of translation, it is imperative to incorporate the rich Internet resources into translation teaching so as to nourish the learners' translation competence. Today the Internet technology development and learners' and teachers' abundant knowledge of computers offer a favorable basis for applying Internet resources to translation teaching. Drawing on research achievements made by other scholars and the experience the authors have reaped in teaching translation, the authors will explore some ways of applying Internet resources to teaching C-E translation to Chinese EFL majors on the university level as an inverse form of translation.

\section{Problems with the Current Translation Teaching Practices}

The translation teaching in foreign languages departments of Chinese universities, generally speaking, has been troubled in recent years by low efficiency of teaching and lack of theoretical guidance (Wang, 2006), due to various causes. The prevailing teaching method is product-oriented and behaviorism-based, which makes it comparatively easy to manage teaching activities, yet not productive of development in translation abilities on the part of the learners. There is no denying that the product-oriented approach has its trouble on either theoretical or practical level. Although what is tangible to the reader is the end product of translation, what can be more helpful to developing the learners' translation abilities is illustrative analysis by the teacher of the translating process that the competent translator has undergone. And if translation is not seen as a process, our understanding of the nature of translating will certainly be impaired. It is inadequate to take into consideration only the "result" of the action of translation. Translation teachers tend to teach in a way based on their personal translation experiences. According to a study made by Zhang (2001), the two most popular translation textbooks in English departments of universities in China are both published first in the 1980s and the relevant teaching theories are seldom incorporated into textbook compilation. Few teaching theories have been applied to translation teaching with considerable achievement. Though there have been some efforts made by some teachers and scholars to research in translation didactics, more need to be done to research and develop more efficient teaching methods, especially those involving Internet resources, which will be more applicable and feasible under the conditions of Chinese EFL majors. 


\section{TRANSlation COMPETENCE: A BRIEF DESCRIPTION}

Analysis of translation competence components can inform theoretically translation teaching. Reflection on the matter is a relatively recent development and results from empirical studies are still scarce (Ezpeleta, 2005). Kelly (2002) reviews the different definitions of translation competence that have been put forward to date and proposes her own definition: Translation competence is the macro-competence that comprises the different capacities, skills, knowledge and even attitudes that professional translators possess and which are involved in translation as an expert activity. She (2002) then cites 7 sub-competencies: communicative and textual, cultural, thematic, professional instrumental, psycho-physiological, interpersonal and strategic, which are intimately related to each other and which, when developed in a particular way, allow translation competence to be acquired. There are, however, aspects that are restricted to the realm of translation and constitute the cornerstone of the definition of translation competence. According to Wang (2009), the specialized component of translation competence, involving three sub-components, i.e. specialized translation knowledge, decision-making on translation strategies and specialized translation operations, is the distinctive part of the translation competence components. Teaching translation to Chinese EFL majors should be oriented to developing their specialized component of translation competence. Though the bilingual competence does not belong to such specialized translation competence, generally speaking, the learners' competence and performance in applying English as a foreign language to C-E translation is not satisfactory. Therefore, the teacher must be aware of the important aspect that the learners are doing inverse translation, i.e. translating from their habitually used language into a foreign language. In the process of translation teaching, there are several factors, besides the teacher and the learner, important to developing the learner's translation competence: teaching models which involve teaching aims, materials as well as methods, and the feedback system. In all such, the computer technology can play a positive role in aiding the learner and the teacher respectively, for the ability to apply such technology (Internet resources as aids included) constitutes an integral part of the learner's translation competence.

\section{InTERnet Resources and Their ReleVAnce to TRAnsLation Pedagogy}

Internet resources are the digital resources in forms of texts, images, sounds, videos, etc. which are deposited in nonpaper carriers like CDs in electronic data form and accessible in websites or web pages (Bi \& Yang, 2002). And these resources of information can be regained through Internet software tools and computers. Internet technology, as a tool, has made it quite convenient to get all kinds of information and resources for daily use, and that is also the reason why Internet resources become indispensable in our life. As Internet resources have been developed and added to every day, there is a great many resources about each of such fields as include translation teaching and learning on Internet. Internet resources which can aid translation teaching and learning include some translation websites, translation corpora, translation software, online dictionaries, online lessons, good translation texts for appreciation, etc. At present, the websites of translation have become more and more popular. On these websites, we can learn translation techniques and skills; we can find materials for daily translation practice; we can exchange our thoughts and experience with others. Among Internet resources, there is also some software which can help us to translate some difficult phrases or words. When confronted with difficulty in translation learning, we can also find help from online dictionaries, online lessons, etc. As Internet resources become so popular and convenient these days, it is certain that the Internet resources will help a lot in translation teaching and learning.

\section{APPLying InTERNET ResourCes to TRANSLATION TEACHING}

\section{A. Using Internet Resources as Source of Information}

Traditionally, translation learners read books, magazines and newspapers to enrich their knowledge, but generally the knowledge gained in this way is quite limited. Now the Internet resources are inexhaustible. On Internet, lots of resources can be accessible, with so much information concerning every field. The traditional way of translation teaching is based on the written or printed teaching materials, which have been used for years without any substantial change of them. By contrast, the language materials on Internet are renewed every day. Today, the EFL majors' obstacles in translating caused by their want of specialized knowledge have been basically overcome with the help of the Internet resources, such as the various editions of encyclopedia and dictionaries, as well as specialized websites.

Translation teaching should aim to activate learners' interest in translation learning, and application of Internet resources to translation teaching is a good way to achieve that effect, which is also quite meaningful to the autonomous learning on the part of the learners. The Internet resources related to translation are innumerable. Internet resources and online dictionaries can help learners understand unfamiliar concepts and words, and check whether the translation results provided by dictionaries are appropriate or not. Thus Internet resources and online dictionaries possess the function of verification. In the process of translating, learners can make sure that their ways of using words and phrases are acceptable and render their translations more accurate and fluent by resorting to these resources. There are some websites serving as platforms for translators to exchange their experience and share translation resources with one another. The translation forum is one of these platforms. Some of these websites may not be designed by professional translators, but they can provide translators with great help which will facilitate their translating work. Websites like 
Google and Wikipedia are good examples of this kind. With all such conveniences brought about by the internet resources for translation learners, there in one point we should not forget: they are only tools, and only when the students have developed their adequate competence and abilities in translating can they benefit from them in their translating work. Here we suppose that the learners have developed their basic translation competence as well as competence in Chinese and English, which means they can judge whether what they get from the internet is dependable (this judging ability does not, however, free them from making mistakes in translation).

Here let's illustrate some basic ways of using Internet resources as a source of information to aid C-E translation by searching in Google.

(1) To find a possible English translation of the book title “史记”, we can search by entering “《史记》 Sima Qian” into the search bar of Google, and then there will come lots of introduction of the book and English versions of the title. The following are some of the results the authors get from this search.

(1) Sima Qian and His Records of the Historian

The author of Records of the Historian is Sima Qian (145 BC-?), who was born in what is now Shaanxi Province. Encouraged by his father, he began to read ancient books when he was still very young. At the age of 20 he started to travel extensively,....

(2) Subsequently, the Chinese ancient civilization with the West have been a general history books - Sima Qian's “Records of the Historian,” Levi's “History of Rome. 随后，中国同西方文明古国先后出现通史著作一司马迁的 《史记》、李维的《罗马史》 $\ldots . . . .$.

(3)《史记》的政治史性质与司马迁的政治思想

Political History Character of Records of the Historian and Sima Qian's Political Thoughts

(2) To search for the back-translating version of the drama title “演艺船” on English websites like Google, we can input “《演艺船》” on the English page of Google, and then we can find the title showboat on this website: http:// bbs.cnstrad.com/ forum.php?mod= viewthread\&tid= 7837 .

(3) To translate the following terms into English “奥肯法则”, “ (体操) 前空翻”, and “现金流量贴现”, we can search these terms on Internet and online dictionaries, and get some versions, which is "the Okun's Law", "forward somersault in the air", and "discounted cash flow" respectively.

(4) To search for the English expressions of the following names of figures and institutions; “洪博培”, “国际清算银 行”, and “萨赫勒旱灾国际干旱委员会”, we’ll find such expressions as “Jon Huntsman”, “Bank for International Settlements", and “the International Arid Sahel Drought Committee” respectively.

(5) To translate the following Chinese institution names into English, we can search “中华人民共和国国家审计署”, “国家质量监督检验检疫总局”, and “国家食品药品监督管理局”, we'll find such translations as “National Audit Office", "General Administration of Quality Supervision, Inspection and Qurantine", and "State Food and Drug Administration" respectively.

(6) To search for some background information, for example, “封禅泰山”, we can find the following information “封禅是一种帝王受命于天下的典礼。这种仪式起源于春秋战国时期, 当时齐、鲁的儒士认为泰山是天下最高 的山......”

Such information will be of great help to translation learners in their efforts in doing C-E translation, which demonstrates advantages the traditional reference materials are not equipped with. Of course, to benefit from the resources, the leaner should be proficient in the language he is working with, and be in a position to judge whether what he has got is proper.

\section{B. Towards a Teaching Strategy through C-E Translation Experiments Aided by Internet Resources}

1. Significance of offering C-E translation experiments

The authors think that translation experiments should constitute an integral part of the overall teaching program of the C-E translation course for Chinese EFL majors on the university level. It can be composed of a series of component experiments involving translation of various materials with specific translation requirements and purposes, with the aid of various online translation resources. In the process the teacher plays the multi-role of a guide, class organizer, information provider, translation initiator, and translation evaluator. Translation teaching can be conducted in a classroom equipped with a network of computers. The teacher's host computer can be connected with the learners' computers to make a small LAN. In this network, the EFL majors as C-E translation learners can carry out experiments designed by the teacher under specific work conditions, and then the teacher collects the results of experiments for analysis and builds translation archives that can be used to construct various corpuses for teaching purposes.

The construction of working conditions intended for conducting translation experiments involves streamlining the interactive channels between the teacher and the students. Through such interactive channels, the teacher can conveniently send translation tasks to students who can also send their translation results to the teachers with ease, for example, through shared e-mails, QQ, or MSN. The teacher, after examining the results, can let students know the feedback of his opinions and comments on their translation performance and answer students' questions online. For these things, the traditional methods of teaching are not so convenient. 
By conducting translation experiments, with so many interesting online resources as aids, the translation learners' initiative of learning E-C translation will be more aroused probably. Meanwhile, the learners can give full play to their subjectivity in learning and develop ability to have autonomous learning activities after class. In experiments, they shall translate according to requirement and fulfill the task assigned by the teacher, which is in itself a process of autonomous learning, and will help them develop self-confidence as learners. The translation experiment can be designed to simulate the real translation conditions where professional translators work based on the technology of multimedia and internet as well as translation software. In real context of professional work, there is proper division of labor between the translators, who make access to rich translation resources including translation corpuses. They fulfill translation work by analysis of the translation requirement of the clients, the context where the translation will be used, and the users. The teacher can design various translation experiments that will be carried out with similar translation conditions as those of the translation companies or agencies. By this way, translation training can train better the learners in their development of professional translation competence and ability to cooperate in teamwork of translation, and thus they will be in a position to adapt themselves with ease to their prospective translation working posts or jobs.

2. General principles of translation experiment design

In formulation of the principle over the translation teaching experiment design, we should consider the various factors relevant to the process of translation teaching, the theoretical basis, and the current translation teaching syllabus and working conditions. Usually the general-purpose language lab with its computer system and internet facilities can meet the need for the present purpose of translation teaching. A translation course website will be of great help in organizing teaching activities including conducting experiments. In the case of experiments, a translation website can be pivotal to interactive activities and communications between the teacher and the students.

Concretely speaking, the principles may include 1) Make translation requirement for experiment clear in specific terms; 2) Vary adequately the field the original Chinese texts belong to, with emphasis on non-literary writings; 3) Make sure that the textual materials are proper as far as the students' bi-lingual proficiency is concerned; 4) Engage the use of online translation resources; 5) Make sure that no translations available for reference in the internet, which means the students should translate by themselves so as to reflect their real translation expertise.

The teacher may design translation experiment guide documents for instructing the learners in doing the experiments, including such items as: the student's personal information (name, registered student number class, grade, etc) and experiment information (time/date, lab, translation resources to be used such as the Google translation function, etc.), the information of translation (the original Chinese text, the translation requirement including translation forms, client and user of translation, etc.), reflection protocols (recording the student's reflection of his translating work in the experiment, the difficult points of the task, etc.). Some information can be included in the task documents and some, in the results submitted by the students. The experiments should form a series as a supplement to the regular classroom instruction. All the design should be done for the ultimate purpose of enhancing translation teaching efficiency and developing the students' translation competence and performance. There is also possibility of developing a mutual complementary relationship between them, or even developing the experiments into a independent course of translation.

3. Translation experiment design: An example

Here the authors suppose that the learners (Chinese EFL majors) are familiar with the required computer operation skills and can conduct the experiment without any technical difficulty. We discuss now an example of translation experiment to illustrate design of translation experiment on C-E translation. The authors choose an original Chinese text used for tourism publicity, which exemplifies the key points of designing an experiment and the process of conducting the experiment. The original Chinese text reads:

始建于唐朝的 $\mathrm{A}$ 寺地处山东省 $\mathrm{B}$ 县西南部, 辖属济宁市, 东临古城曲阜, 西接水泊梁山, 南依微山湖, 北 枕东岳泰山。全县人口 74 万, 总面积 877 平方公里。公元 1008 年, 宋真宗皇帝封禅泰山时曾驻趾于此。寺内 太子灵踪塔始建于北宋政和二年（公元 1112 年），1977 年被列为省级重点文物保护单位。1994 年 3 月 15 日 在修葺古塔时, 发现了隐没于塔底的塔宫, 并在宫中出土了包括佛牙舍利在内的 141 件佛教圣物。此事轰动了 全国, 震惊了世界, 引起了海内外强烈反响。

The translation task requirement may be: the translated version in English should be accurate in terms of message free from distortion of the original information and the cultural information should be treated properly; the translation form is full translation; the translation is to be used by a tourist agency as an introducing text oriented to English readers; total experiment time is 90 minutes. The resources the learner can make use of may be any online resources, including online dictionaries, encyclopedia, and translation software. After an experiment, the student shall fill out a form to report the results of the experiment. The translation result submitted by a learner should include the finished English version, the major translation resources the student uses, and the learner's reflection on the specific translation work, or perhaps some constructive suggestions on translation experiments.

The learner, after getting the translation task instruction through the internet link in the computer designated for him, should first analyze the translation requirement and think about his specific translation strategy involving analysis of the function of the Chinese text, the purpose of translation, and other relevant factors. After such analysis, he can proceed to translate with the aid of online translation resources. In the process, we can take it that he uses some online translation resources first in trying to get a thorough comprehension of the original Chinese text on various levels, and then in solving some difficult points such as translation of a phrase or a word, and he may find some similar materials in 
English in the field for stylistic polish of his English version. With all these efforts, he fulfills his task of translation, and writes some reflection on his translation work. Finally he submits the experiment result containing all required information. Then the experiment is fulfilled by the learner. The teacher will get the results and evaluate the learners' performance for necessary feedback and for the purpose of improving his translation teaching.

After collecting the results of the experiments, the teacher can analyze the collection for various purposes. With the aid of corpus technology, he can build purpose-specific corpuses. For the same original text, the collection of all the students' translations can form a corpus for analysis of some possible common trouble with the students' translations, which the teacher may discuss with the learners for improvement. This use is immediately relevant with translation teaching. If over a period of time there is a large collection of translations gathered, they can form translation archives (Bowker, 2007). From the collection, the teacher can select translations to build a corpus for longitudinal comparative study on the progress the learners have achieved in learning translation over a period, and if the progress is obviously substantial, it is surely positive for the learners to enhance their confidence in learning and practicing translation. The learner's reflection on his translation work may be valuable to the teacher for an understanding of the former's process of translation.

\section{CONCLUSION}

The abundant internet resources available have brought about many new possibilities of ways of applying Internet resources to translation teaching in order to enhance the performance of teaching the C-E translation course to Chinese EFL majors. The paper explores some possibilities of applying internet resources to teaching C-E translation to Chinese EFL majors on the university level. Improvement in performance of translation teaching is conducive to nourishment of translation talents. Translation experiments can be a feasible way which will probably lead to better teaching results. Through designing and making translation experiment, the teacher-learner interactive relationship will be strengthened, and the learners' learning initiative on an autonomous basis can be more aroused in developing their C-E translation ability, thus enhancing translation teaching efficiency. The design of the C-E translation experiments should be governed by some principles and oriented to developing the translation competence of the learners by imitating real conditions where professional translators work.

\section{REFERENCES}

[1] Bao, Chuanyun (2003). Some Views on Translation Teaching. Journal of Chinese Translators 2, 35-37.

[2] Bi, Qiang \& Wenxiang Yang. (2002). Development and Application of Internet Information Resources. Beijing: Press of Science.

[3] Bowker, L. (2007). Corpus-based applications for translator training: Exploring the possibilities. In S. Granger, et al (eds.) Corpus-based Approaches to Contrastive Linguistics and Translation Studies. Beijing: FLTRP, 169-184.

[4] Ezpeleta, P. (2005). La noción de género en la planificación de la traducción de la primera lengua extranjera. In I. García Izquierdo (ed.) El género textual y la traducción. Reflexiones teóricas y aplicaciones pedagógicas. Bern: Peter Lang, 135-138.

[5] Kelly, D. (2002). Un modelo de competencia traductora: bases para el diseño curricular. In P. Padilla, et al (eds.) Puentes, Hacia nuevas investigaciones en la mediación intercultural(1). Granada: Albolote: 9-20.

[6] Wang, Xiaonong. (2006). On Teaching C-E Translation to Big Classes of Chinese EFL Majors. Shandong Foreign Language Teaching 1, 68-72.

[7] Wang, Xiaonong. (2009). On Professional Translation Competence and Translation Teaching offered for Chinese EFL Majors. Journal of Tangshan Normal College 1,157-160.

[8] Zhang, Meifang. (2001). A Study of the E-C Translation Textbooks for Chinese EFL Majors: 1949-1998. Shanghai: Shanghai Foreign Language Education Press.

Xiaonong Wang (corresponding author) was born in 1968 in Zibo, China. He received his MA degree in linguistics from Shandong University, China, in 2003.

$\mathrm{He}$ is currently an associate professor in School of Foreign Languages, Ludong University, Yantai, Shandong, and has worked as a teacher of translation and translator between Chinese and English for more than a decade. He is now doing a doctoral program in College of Foreign Languages, Nankai University, Tinjian, China. Interested in translation studies from a cognitive perspective, he co-authored two books on study of textual translation on the basis of Cognitive Linguistics. He is also the author of a book on applying English for practical purposes with special reference to translation from Chinese into English, and published a series of scholarly papers concerned with teaching translation to Chinese EFL majors on the university level.

Bo Chang was born in 1971 in Zibo, China. She received his BA degree in Literature from Ludong University, China, in 2010.

She is currently a lecturer in the Multimedia Instruction Management Center, Ludong University, Yantai, China. Her research interest is application of CAT in teaching. 